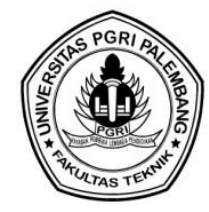

\title{
EVALUASI KEKUATAN PERKERASAN SISI UDARA (RUNWAY, TAXIWAY DAN APPRON) BANDARA SULTAN MAHMUD BADARUDDIN II PALEMBANG DENGAN METODE PERBANDINGAN ACN-PCN
}

\author{
Amiwarti $^{1 *}$, Herri Purwanto ${ }^{2}$, Asep Sulaiman $^{3}$ \\ ${ }^{123}$ Prodi Teknik Sipil FakultasTeknik Universitas PGRI Palembang \\ Jalan Jend A. YaniLr. Gotong Royong 9/10 Ulu Palembang Sumatera Selatan \\ "Corresponding Author, Email: amiwarti@yahoo.com
}

\begin{abstract}
ABSTRAK
Pengembangan sisi udara bandara Sultan Mahmud Badaruddin II Palembang kini memiliki panjang runway $3.000 \times 45 \mathrm{~m}$. Fasilitas sisi udara merupakan fasilitas pergerakan pesawat. Fasilitas ini harus memenuhi kekuatan struktur untuk melayani pergerakan-pergerakan pesawat yang beroperasi sesuai dengan perencanaan. Tujuan penelitian ini adalah untuk mengevaluasi apakah perkerasan sisi udara di Bandar Udara Sultan Mahmud Badaruddin II Palembang ini sudah memenuhi batas PCN yang dipersyaratkan atau belum. Analisa dilakukan dengan cara mengevaluasi kekuatan perkerasan sis iudara (runway,taxiway, dan Apron) eksisting menggunakan metode perbandingan ACN-PCN yang didapat dari pabrik pembuat pesawat, perhitungan manual dan Softwere COMFAA 3.0 Data yang digunakan adalah data pergerakan pesawat termasuk jumlah pergerakan pertahun dan tipe pesawat. Data kekuatan perkerasan sisi udara diperlukan untuk proses analisa. Hasil dari evaluasi menunjukan bahwa pada saat kondisi eksisting sisi udara yang berupa runway, taxiway, dan apron masih mampu melayani permintaan penerbangan dengan jenis pesawat Boeing 747-400ER yang memiliki nilai PCN 42 F/C/X/T untuk Apron dan PCN 43 F/C/X/T untuk Runway/Taxiway. Besar Nilai ACN Pesawat B747-400ER ini tidak mempengaruhi kekuatan structural karena frekuensipergerakanhanya 421 pergerakan per tahun, mengingat frekuensi penerbangan masih dibawah 10.000 pergerakan.
\end{abstract}

Kata Kunci : ACN, PCN, COMFA 3.0, Kekuatan Perkerasan.

\section{PENDAHULUAN}

Indonesia adalah negara kepulauan yang memiliki lebih 17 ribu pulau dengan total wilayah $1.904 .569 \mathrm{~km}^{2}$ yang memerlukan transportasi cepat dan aman guna mendorong kemajuan ekonomi nasional, maka angkutan udara memegang peran penting guna menghubungkan antar pulau dengan cepat dan tepat waktu. Selain itu di Indonesia terdapat bandar udara yang sangat besar yaitu, 26 yang dikelola oleh BUMN, PT.(Persero) Angkasa Pura II, dan UPT daerah/pemda sebanyak 29. Sedangkan unit penyelenggaran bandar udara sebanyak 236.(Dirtjen Perhub,2015). Bandar udara adalah kawasan dengan batas-batas tertentu yang digunakan sebagai tempat pesawat udara, (Djoko Warsito, 2017 dalam Purwanto, H. 2019)

Jumlah penumpang yang menggunakan jasa penerbangan sipil selalu meningkat dari tahun ketahun dan kebutuhan para maskapai akan pesawat yang efisien direspon para produsen pesawat terbang sipil yang setiap dekade selalu meluncurkan pesawat terbang jarak jauh yang berkapasitas besar dengan bahan bakar hemat (R.H Triharso Seno,2015)

Landasan hubung dan landasan pacu Bandar Udara Sultan Mahmud Badaruddin II Palembang dibangun pada tahun 1970 untuk pesawat DC-9. Pesawat yang beroperasi di Bandara Sultan Mahmud Badaruddin II Palembang hingga tahun 2019 bervariasi dan 
mempengaruhi nilai ACN dari masing-masing pesawat tersebut. Dengan data nilai PCN pada fasilitas sisi udara seperti yang disebutkan tersebut timbul suatu pertanyaan berkaitan dengan kekuatan perkerasan sisi udara dalam menerima beban pesawat yang bervariasi. Penelitian ini dimaksudkan untuk mengevaluasi kekuatan perkerasan sisi udara Bandara Sultan Mahmud Badaruddin II Palembang akibat variasi pergerakan pesawat dengan membandingakan nilai ACN dan PCN.

Dalam kegiatan perancangan bandar udara, diklasifikasikan berdasarkan pesawat yang dapat dilayani, Suharno,H,2015. Di bandar udara, terdapat berbagai pesawat dengan lebar yang bervariasi, mulai dari pesawat kecil (small general aviation) hingga pesawat besar (heavy air transport aircraft), Horonjeff,R.dkk,2010. Bandar udara dirancang berdasarkan pesawat kritis (critical) atau pesawat rencana (design).

Menurut Heru Basuki 1986, konfigurasi lapangan terbang dalam jumlah dan arah (orientasi) dari landasan serta penempatan bangunan terminal termasuk lapangan parkirnya yang terkait dengan landasan pacu. Jumlah landasan tergantung pada volume lalu lintas, dan orientasi landasan bergantung kepada arah angin dominan yang tertiup, tetapi kadang-kadang juga luas tanah yang tersedia bagi pengembangan ada pengaruhnya.

\section{METODE PENELITIAN}

Menurut Arikunto dalam Amiwarti 1998, Penelitian ini menggunakan metode yang ditempuh dari awal hingga akhir dan lebih bersifat eksperimental.

Adapun langkah yang dilakukan adalah :

1. Mengidentifikasi potensi masalah yaitu setelah sekian lama pesawat terbesar beroperasi dibandara Sultan Mahmud Badaruddin II Palembang, belum pernah ada kajian terhadap PCN fasilitas sisi udara atas ACN.

2. Mengumpulkan data yang dimiliki oleh pengelola bandara (jenis pesawat, fekunsi, PCN, MTOW pesawat. pengumpulan data jenis pesawat, MTOW pesawat dan Frekuensi dapat diperoleh dari Airport Readiness Department

3. Data Pergerakan pesawat Boeing 747-400ER di Bandara Sultan Mahmud Badaruddin

4. Sudi literatur dengan metode penentuan ACN pesawat terhadap perkerasan yang dilaluinya.

5. Membandingakan teori dengan data yang sudah terkumpul yaitu apakah jumlah pergerakan pesawat di bandara Sultan Mahmud Badaruddin II Palembang masih dalam batas maksimal atau sudah melebihi batas.

6. Menganalisis kondisi fasilitas sisi udara eksisting, terutama dari sisi kekuatan dan akibat yang terjadi kedepannya.

7. Seluruh perbandingan diatas dilakukan terhadap perkerasan lentur, perkerasan kaku, landas hubung dan tempat parker pesawat.

8. Memberikan masukan kepada pengelola bandara tentang kondisi perkerasan fasilitas sisi udara dengan pesawat yang beroperasi saat ini.

\section{HASIL DAN PEMBAHASAN}

Setelah dilakukan perhitungan untuk seluruh jenis pesawat pada perkerasan lentur dan perkerasan kaku, hasilnya disajikan pada tabel 1 dan tabel 2 berikut ini: 
Tabel 1. Nilai ACN pesawat dengan perkerasan Lentur

\begin{tabular}{|c|l|c|c|c|c|c|c|c|c|}
\hline \multirow{2}{*}{ No } & \multirow{2}{*}{ Type Pesawat } & \multicolumn{4}{|c|}{ Manufacture } & \multicolumn{4}{c|}{ COMFAA } \\
\cline { 3 - 10 } & & A & B & C & D & A & B & C & D \\
\cline { 3 - 10 } & & 15 & 10 & 6 & 3 & 15 & 10 & 6 & 3 \\
\hline 1 & Boeing 737-900ER & 48 & 51 & 56 & 61 & 47,9 & 50,8 & 56,0 & 60,8 \\
\hline 2 & Boeing 737-800 & 43 & 45 & 50 & 55 & 42,8 & 45,3 & 50,3 & 55,2 \\
\hline 3 & Boeing 747-400ER & 57 & 63 & 78 & 100 & 56,7 & 63,4 & 77,8 & 99,8 \\
\hline 4 & Airbus 320-200 & 34 & 35 & 39 & 45 & 38,5 & 40 & 4,4 & 50,2 \\
\hline 5 & Cessna 172 & & & & & 0,5 & 0,6 & 0,8 & 1,0 \\
\hline 6 & Learjet 35 & 4 & 5 & 5 & 6 & 4,3 & 4,4 & 5 & 5,6 \\
\hline 7 & Boeing 737 & 34 & 35 & 39 & 45 & 24,9 & 25,7 & 28.9 & 33,1 \\
\hline
\end{tabular}

Sumber :Hasil survey

Tabel 2. Nilai ACN pesawat dengan perkerasan Kaku

\begin{tabular}{|c|l|c|c|c|c|c|c|c|c|}
\hline \multirow{2}{*}{ No } & \multirow{2}{*}{ Type Pesawat } & \multicolumn{4}{|c|}{ Manufacture } & \multicolumn{5}{c|}{ COMFAA } \\
\cline { 3 - 10 } & & A & B & C & D & A & B & C & D \\
\cline { 3 - 10 } & $\begin{array}{c}15 \\
0\end{array}$ & 80 & 40 & 20 & 150 & 80 & 40 & 20 \\
\hline 1 & Boeing 737-900ER & 56 & 58 & 60 & 62 & 55,6 & 58,2 & 60,6 & 62,6 \\
\hline 2 & Boeing 737-800 & 49 & 51 & 54 & 56 & 49,2 & 51,7 & 54,1 & 56,1 \\
\hline 3 & Boeing 747-400ER & 69 & 69 & 81 & 92 & 59,1 & 69,8 & 81,7 & 92,5 \\
\hline 4 & Airbus 320-200 & 33 & 40 & 42 & 44 & 44 & 46,0 & 48,4 & 50,4 \\
\hline 5 & Cessna 172 & & & & & 0.7 & 0,8 & 0,8 & 0,6 \\
\hline 6 & Learjet 35 & 5 & 5 & 6 & 6 & 5,2 & 5,4 & 5,6 & 5,7 \\
\hline 7 & Boeing 737 & 27 & 29 & 31 & 32 & 27 & 29 & 31 & 32 \\
\hline
\end{tabular}

Sumber :Hasil survey

Sesuai dengan FAA Advisory CircularAC 150/5335-5C. nilai PCN runway/taxiway/apron memiliki format baku yang terdiri dari 6 (enam) karakter. Sebagai contoh Main Apron memiliki PCN $=72 \mathrm{R} / \mathrm{C} / \mathrm{W} / \mathrm{T}$ maksud dari masing-masing karakter tersebut adalah: $\mathrm{R}=$ Rigid, perkerasan kaku $; \mathrm{C}=$ Subgrade low, nilai CBR tanah dasar $5 \%-8 \% ; \mathrm{X}=$ Tekanan rodahigh (Tidak Terbatas) $; \mathrm{T}=$ Technikal, angka 72 ditentukan dengan menggunakan uji cobapesawat.

Selanjutnya nilai angka di ACN kita bandingkan dengan nilai angka di PCN Apron tersebut, apakah lebih besar atau lebih kecil. Setelah itu kode huruf karakter kedua yaitu nilai subgrade pada ACN versi Aircraft Manu facturer /COMFAA (A, B, C atau D) kita bandingkan yang sesuai yaitu dengan nilai $=\mathrm{C}^{\text {' }}$ dari $\mathrm{PCN}$ apron tersebut, apakah lebih besar atau lebih kecil.

Diambil contoh PCN Apron $=72 \mathrm{R} / \mathrm{C} / \mathrm{X} / \mathrm{U}$ akan dibandingkan dengan ACN pesawat Boeing 747 - 400 ER,maka analisisnya adalah sebagai berikut :

a. Jenis perkerasan $=k a k u$ (rigid pavement)

b. Nilai ACN dengan subgrade $\mathrm{C}$ versiversi Aircraft Manufacturer $=81$, versiCOMFAA $=81,7$ 
ACN pesawat tersebut sudah pasti melebihi dari PCN Main Apron, akan tetapi pesawat masih diperbolehkan menggunakan Main Apron karena frekuensi pesawat tersebut adalah 421pergerakan per tahun, (lebih kecil dari 10.000 pergerakan per tahun) sesuai batasan dari FAA Advisory Circular AC 150/5335-5C.

Karakteristik operasional untuk masing-masing jenis pesawat yang beroperasi adalah sebagai berikut :

Tabel 3. Jumlah Pergerakan Pesawat

\begin{tabular}{|c|c|c|}
\hline No & Jenis Pesawat & $\begin{array}{c}\text { Kedatangan } \\
\text { per tahun }\end{array}$ \\
\hline 1 & Boeing 737-900ER & 1.333 \\
\hline 2 & Boeing 737-800 & 948 \\
\hline 3 & Boeing 747-400ER & 8.343 \\
\hline 4 & Airbus 320-200 & 1.663 \\
\hline 5 & Cessna 172 & 1.575 \\
\hline 6 & Learjet 35 & 876 \\
\hline 7 & Boeing 737 & 1.872 \\
\hline
\end{tabular}

Dari table diatas diketahui bahwa pesawat dengan Gross Weight terbesar yaitu Learjet 35 hanya memiliki pergerakan 876 pesawat per tahun yang memiliki pergerakan paling sering adalah B747-400ER yaitu 8343 pesawat pertahun atau 90 pesawat per hari.

\section{KESIMPULAN}

Dihasilkan suatu proses evaluasi terhadap kemampuan pelayanan perkerasan sisi udara Bandara Sultan Mahmud Badaruddin II Palembang untuk operasional harian. Dalam hal ini ada tiga permasalahan yang harus diselesaikan, yaitu berkaitan dengan karakteristik operasional pesawat, nilai ACN dari pesawat-pesawat tersebut, serta overload apabila nilai $\mathrm{ACN}>\mathrm{PCN}$.

1. Hasil Perbandingan ACN pesawat dengan PCN perkerasan fasilitas sisi udara di Bandara Sultan Mahmud Badaruddin II Palembang menunjukkan bahwa pesawat B747-400ER memiliki nilai ACN $<$ PCN untuk perkerasan kaku dan lentur.

2. Karakteristik pesawat dengan nilai $A C N<P C N$ memiliki frekuensi pergerakan 421/tahun. Hasil evaluasi menunjukkan bahwa perkerasan sisi udara masih mampu dan layak melayani pesawat berbadan lebar tersebut, mengingat frekuensi pergerakan pesawat masih dibawah 10.000 per tahun. Karena lebih kecil dari 10.000 pergerakan pertahun, maka tidak ada analisis overload.

3. Batasan nilai PCN juga harus memperhatikan tekanan roda yang diijinkan. Tekanan roda mempengaruhi besarnya contact stress. Pada kecepatan tinggi menimbulkan friksi besaran tararoda dan permukaan perkerasan. 
4. Kondisi ini mengakibatkan timbulnya rubber deposit dan permukaan perkerasan yang semakin halus. Untuk kekesatan permukaan landasan pacu, Mu Meter Run Report pada bulan November 2017 didapatkan nilai 0,56. Dengan pengukuran tersebut, maka tidak diperlukan tindakan atau korelasi yang dilakukan. Kondisi ini memperlihatkan bahwa tingkat kekesatan dalam kondisi menurun tetapi masih dalam kondisi aman.

\section{DAFTAR PUSTAKA}

Arikunto, Suharsimi,1998, Amiwarti, Prosedur Penelitian Suatu Pendekatan Praktek, dalam https://jurnal.univpgri-palembang.ac.id/index.php/deformasi/article/view/ 915/767

Basuki, H., (1986). Merancang dan Merencana LapanganTerbang. Alumni. Bandung. Horonjeff, et al 2010. Planning and Design of Airports, fifth Edition, Mc. Graw-Hill Inc

Peraturan Dirtjen Perhub RI No. PM 81 Tahun 2017. Perubahan atas peraturan Menteri Perhubungan No PM 94 Tahun 2015 Tentang Peraturan Keselamatan Penerbangan Sipil Bagian 91 (Civil Aviation Safety Regulation Part 91) Tentang pengoperasian Pesawat Udara (General Operating and Flight Rules). September 2017

Sartono, Wardhani. Dkk. 2017. Bandar Udara Pengenalan dan Perancangan Geometrik Runway, Taxiway, dan Apron. Gajah Mada University Press, Yogyakarta.

Seno, Triharso, H.R dan Ahyudanari E. 2015. Evaluasi Kekuatan Perkerasan Sisi Udara (Runway,Taxiway,dan Apron) Bandara Juanda dengan Metode Perbandingan $A C N-P C N$, Dalam Jurnal Teknik ITS Vol. 4, No. 1

Suharno, Hadi. 2015. Manajemen dan Perencanaan Bandar Udara, Ed 2,-2 Rajawali Pers, Jakarta.

Warsito, Djoko, dalam Purwanto, H (2019), https://jurnal.univpgri-palembang.ac.id/ index.php/deformasi/article/view/2971/2795 